Penerapan Model Pembelajaran Kooperatif Tipe Numbered Heads Together (NHT) terhadap Aktivitas Belajar Siswa pada Materi Ikatan Kimia Kelas X I SMA Negeri 3 Watampone

\title{
Penerapan Model Pembelajaran Kooperatif Tipe Numbered Heads Together (NHT) terhadap Aktivitas Belajar Siswa pada Materi Ikatan Kimia Kelas X 1 SMA Negeri 3 Watampone
}

The Implementation of Cooperative Learning Model of Numbered Heads Together (NHT) Type toward the Student's Learning Activity Completeness of Class X SMA Negeri 3 Watampone on Chemical Bonding

\author{
Sitti Nurpaidah \\ SMA Negeri 3 Watampone, Kabupaten Bone 92735 \\ Email: chaculenurpaidah@gmail.com
}

\begin{abstract}
ABSTRAK
Penelitian ini bertujuan untuk menerapkan pembelajaran tipe numbered heads together (NHT) untuk mengetahui aktivitas belajar siswa pada materi ikatan kimia siswa Kelas X 1 SMA Negeri 3 Watampone. Penelitian ini dilaksanakan sebanyak 2 siklus dan setiap siklus dilakukan sebanyak empat kali pertemuan termasuk tes setiap akhir siklus. Pengumpulan data dilakukan dengan teknik observasi terhadap aktifitas siswa setiap akhir siklus di kelas tersebut dan catatan lapangan selama tindakan pembelajaran berlangsung. Dalam penelitian ini terlihat jelas bagaimana perubahan aktivitas siswa ketika pembelajaran berlangsung yaitu: (1) Siswa yang hadir selama siklus I mencapai 95\% dan pada siklus II ada peningkatan menjadi 100\%. (2) Siswa yang memperhatikan dan mencatat pelajaran mencapai $73,33 \%$ dan pada siklus II mencapai 96,67\%. (3) Siswa yang aktif dalam diskusi kelompok pada siklus I dan siklus II sama-sama mencapai $100 \%$, (4) Siswa yang bertanya tentang materi bahan ajar yang kurang jelas pada siklus I mencapai $8,34 \%$ dan pada siklus II mencapai 0\%, (5) Siswa yang aktif dalam pemecahan masalah pada siklus I mencapai $40 \%$ dan pada siklus II mencapai $45 \%$. (6) Siswa yang menjelaskan hasil diskusi kelompok di papan tulis mencapai 31,67\% dan pada siklus II mencapai 53,33\%.
\end{abstract}

Kata Kunci : NHT, Aktivitas belajar, Ikatan kimia 
Penerapan Model Pembelajaran Kooperatif Tipe Numbered Heads Together (NHT) terhadap Aktivitas Belajar Siswa pada Materi Ikatan Kimia Kelas X I SMA Negeri 3 Watampone

\begin{abstract}
This study aims to apply the Numbered Heads Together (NHT) learning method to determine student learning activities in the material of chemical bond of Class X 1 students of SMA 3 Watampone.This study was conducted in 2 cycles and each cycle is done as much four meetings including tests at each end of the cycle. Data collection is done by observation techniques to student activities and evaluation of learning outcomes at each end of the cycle in the class and field notes during the learning action. In this study it is clear how changes in student activity when learning takes place are: (1) Students who present during the cycle of the I reached $95 \%$ and a cycle II no increase in a 100\%. (2) Students noticed and record the lessons achieve $73,33 \%$ and at the cycle II achieve $96,67 \%$. (3) Students active in the group discussions on cycle I and cycle II same the same reach $100 \%$. (4) Students who asked about the material teaching materials less clear on cycle I achieve $8,34 \%$ and at the cycle II reach $0 \%$. (5) Students active in resolution on cycle I reach $40 \%$ and at the cycle II reach $45 \%$. (60 students who describes the results discussion groups in the board achieve $31,67 \%$ and at the cycle achieve 53,33\%.
\end{abstract}

Keywords: NHT, Learning activity, Chemical bonding

\section{PENDAHULUAN}

Materi Pelajaran Kimia di SMA banyak berisi konsep-konsep yang cukup sulit untuk dipahami siswa, karena menyangkut reaksi-reaksi kimia dan hitungan-hitungan serta menyangkut konsep-konsep yang bersifat abstrak dan dianggap oleh siswa merupakan materi yang relatif baru. Oleh sebab itu, diperlukan suatu usaha untuk mengoptimalkan pembelajaran kimia di kelas dengan menerapkan pendekatan dan metode yang tepat.

Guru telah menggunakan variasi metode dalam pembelajaran seperti diskusi kelompok, praktikum, demonstrasi, meskipun masih sering menggunakan metode konvensional atau metode ceramah. Penggunaan variasi metode ini dirasa kurang maksimal, terlihat dari hasil belajar ( $\leq$ $50 \%$ ketuntasan).
Hal ini terlihat dari suasana kelas dimana dalam pross belajar mengajar rata-rata hanya siswa yang memiliki intelegensi yang tinggi dan berstatus sosial lebih tinggi yang terlihat aktif dalam pembelajaran sedangkan siswa yang biasa-biasa saja berperan sebagai pelengkap dalam kelas saja. Padahal tidak menutup kemungkinan informasi terbaru dan ide-ide yang kreatif dapat muncul dari siswa yang biasa-biasa saja.

Dengan demikian, mengatasi permasalahan tersebut dengan memberikan metode yang variatif untuk lebih mengaktifkan siswa, salah satunya adalah model pembelajaran kooperatif tipe Numbered Head Together (NHT). Model pembelajaran tipe NHT ini cukup variatif dan benarbenar melibatkan keaktifan setiap siswa dalam proses belajar mengajar (Arends, 20008; Hobri, 2009). 
Selain itu, siswa yang memiliki intelegensi yang lebih tinggi diharapkan mampu memberikan pengarahan atau berbagi pengetahuan dengan siswa lain sebab metode ini menekankan pada kerjasama tim yang solid dimana tidak ada yang bertindak sebagai ketua kelompok yang bertanggungjawab terhadap keberhasilan tim melainkan semua anggota kelompoklah yang harus bertanggungjawab terhadap keberhasilan tim.

Materi yang dipilih dalam penelitian ini adalah materi ikatan kimia meliputi bahasan Kestabilan Unsur, Struktur Lewis, ikatan ion, ikatan kovalen, Ikatan kovalen koordinasi, Kepolaran senyawa kovalen dan Ikatan Logam. Biasanya, kesulitan yang dialami siswa dalam mempelajari kimia bersumber pada kesulitan dalam memahami istilah dan kesulitan dalam memahami konsep kimia. Kesulitan siswa dalam memahami istilah dan konsep kimia dapat menimbulkan pemahaman yang salah dan jika pemahaman yang salah ini berlangsung secara konsisten akan menimbulkan terjadinya kesalahan konsep. Siswa yang mengalami kesalahan konsep akan memiliki pemahaman konsep yang berbeda dengan pemahaman yang diterima oleh masyarakat ilmiah.

Berdasarkan uraian di atas, penelitian ini bertujuan menerapkan model pembelajaran kooperatif tipe Numbered Heads Together (NHT) untuk mengetahui aktivitas belajar siswa pada materi ikatan kimia siswa Kelas X 1 SMA Negeri 3 Watampone.

\section{METODE PENELITIAN}

Penelitian ini merupakan penelitian tindakan kelas dan Subjek penelitian adalah siswa kelas $\mathrm{X} \quad 1$ semester ganjil dengan jumlah 30 orang yang terdiri dari 13 orang laki-laki dan 17 orang perempuan.

Observasi awal penelitian menetapkan materi "Ikatan kimia" dengan strategi pembelajaran NHT yang memuat 2 kompetensi dasar yang terdiri dari 8 indikator, materi tersebut dipenggal menjadi 4 kali pertemuan dan dibagi menjadi 2 siklus, yaitu siklus I evaluasi setelah pertemuan I sampai II dan siklus II evaluasi setelah pertemuan I sampai II.

Gambaran Siklus I, dapat di jabarkan sebagai berikut:

1. Perencanaan dengan menelaah kurikulum 2006, membuat RPP dan LKS (tugas kelompok), membuat observasi, membuat dan menyusun alat evaluasi misalnya kisi-kisi, kartu soal, dan soal evaluasi,

2. Pelaksanaan penelitian tindakan kelas sesuai langkah pembelajaran NHT yang mengacu kepada pendahuluan, kegiatan inti, dan penutup.

3. Penggunaaan lembar observasi meliputi kehadiran, siswa yang memperhatikan dan mencatat pelajaran, siswa yang tidak memperhatikansiswa yang aktif dalam diskusi kelompok, siswa yang bertanya tentang materi bahan ajar yang kurang jelas, siswa yang aktif dalam pemecahan masalah, dan siswa yang menjelaskan hasil diskusi kelompok. 
Penerapan Model Pembelajaran Kooperatif Tipe Numbered Heads Together (NHT) terhadap Aktivitas Belajar Siswa pada Materi Ikatan Kimia Kelas X I SMA Negeri 3 Watampone

4. Refleksi, pengkajian terhadap hasil tindakan yang telah dilakukan apakah berhasil sesuai dengan rencana atau tidak dengan tujuan sementara untuk menentukan tindakan terhadap siklus berikutnya.

Gambaran Siklus II, meliputi:

1. Perencanaan dengan menganalisis hasil refleksi dari siklus I dan membuat persiapan pelaksanaan siklus II serta menjadikan kelemahan-kelemahan pada siklus I sebagai penguatan.

2. Pelaksanaan tindakan mengacu pada model pembelajaran NHT.

3. Penggunaan lembar observasi sama dengan siklus I.

4. Refleksi adalah pengkajian hasil tindakan yang telah dilakukan, apakah meningkat dibandingkan hasil refleksi I atau tidak. Bila ada perubahan peningkatan, menandakan bahwa pembelajaran tipe Numbered Heads Together (NHT) adalah baik digunakan.

Keberhasilan pada penelitian ini mengarah pada hasil analisis data adanya perubahan keaktifan belajar siswa dari siklus I ke siklus II. Untuk mengukur keberhasilan tersebut digunakan skor ketercapaian.

\section{HASIL DAN PEMBAHASAN}

Penelitian ini dilaksanakan dua siklus, siklus I sebanyak dua pertemuan dan siklus II sebanyak dua pertemuan, pelaksanaan observasi setiap pertemuan yang indikatornya keaktifan belajar siswa dan evaluasi hasil belajar setiap akhir siklus.

\section{A. Observasi Aktifitas Belajar Siswa pada Siklus 1}

Data tentang keaktifan belajar siswa sebagai pelaksanaan tindakan pada siklus I dikumpul melalui pengamatan oleh anggota team yang menyangkut rata-rata persentase yang menyangkut rata-rata persentase yang termuat dalam Tabel 1.

Tabel 1. Data Observasi Aktifitas Belajar Siswa Siklus I

\begin{tabular}{|c|c|c|c|c|}
\hline \multirow{2}{*}{ No } & \multirow{2}{*}{$\begin{array}{l}\text { Aktivitas Siswa } \\
\text { Selama } \\
\text { Pembelajaran }\end{array}$} & \multicolumn{2}{|c|}{$\begin{array}{c}\text { Pertemuan } \\
\text { ke- }\end{array}$} & \multirow{2}{*}{$\begin{array}{l}\text { Rata- } \\
\text { rata } \\
(\%)\end{array}$} \\
\hline & & I & II & \\
\hline 1 & Siswa yang hadir & 28 & 29 & 95 \\
\hline 2 & $\begin{array}{l}\text { Siswa yang } \\
\text { memperhatikan } \\
\text { dan mencatat }\end{array}$ & 20 & 24 & 73,33 \\
\hline 3 & $\begin{array}{l}\text { Siswa yang tidak } \\
\text { memperhatikan }\end{array}$ & 3 & 1 & 6,67 \\
\hline 4 & $\begin{array}{l}\text { Siswa yang aktif } \\
\text { dalam diskusi } \\
\text { kelompok }\end{array}$ & 27 & 28 & 91,67 \\
\hline 5 & $\begin{array}{lr}\text { Siswa yang } \\
\text { bertanya tentang } \\
\text { materi bahan ajar } \\
\text { yang } \\
\text { jelas }\end{array}$ & 3 & 2 & 8,34 \\
\hline 6 & $\begin{array}{l}\text { Siswa yang aktif } \\
\text { dalam } \\
\text { pemecahan } \\
\text { masalah }\end{array}$ & 9 & 15 & 40 \\
\hline 7 & $\begin{array}{l}\text { Siswa yang } \\
\text { menjelaskan } \\
\text { hasil diskusi } \\
\text { kelompok } \\
\text { dipapan tulis }\end{array}$ & 6 & 13 & 31,67 \\
\hline
\end{tabular}


Data observasi pada Tabel 1 bahwa siswa yang hadir mencapai $95 \%$, yang memperhatikan dan mencatat pelajaran mencapai $73,33 \%$, siswa yang tidak memperhatikan $6,67 \%$, siswa yang aktif dalam diskusi kelompok sebesar $100 \%$, siswa yang bertanya tentang materi bahan ajar yang kurang jelas mencapai $8,34 \%$, siswa yang aktif dalam pemecahan masalah sebesar $40 \%$, dan siswa yang menjelaskan hasil diskusi kelompok di papan tulis mencapai $31,67 \%$. Kesimpulan dari analisis tersebut bahwa keaktifan belajar siswa belum mencapai apa yang diharapkan dengan indikasi rata-rata indikator keaktifan belum mencapai 100 persen.

Hasil refleksi pada siklus I, terdapat beberapa kekurangan pada proses belajar mengajar dengan menggunakan metode pembelajaran kooperatif yang akan ditindaklanjuti pada siklus II. Adapun hasil refleksi siklus I adalah sebagai berikut: sikap siswa pada umumnnya masih kurang memberikan tanggapan positif terhadap metode yang digunakan dan dan berdasarkan hasil observasi, yakni kurangnya perhatian serius dari siswa sehingga dalam menanggapi materi atau mengerjakan soal-soal latihan atau tugas yang diberikan seadanya saja.

Meskipun soal-soal yang diberikan sebagai latihan dibuat semirip mungkin dengan soal yang dicontohkan sebelumnya, terlihat dari hasilnya masih banyak yang mendapatkan kesulitan. Hal ini disebabkan karena siswa beranggapan bahwa soal-soal yang diberikan tersebut tidak diberi nilai atau tidak dipengaruhi nilai siswa nantinya kalau siswa aktif mengerjakan tugas di papan tulis. Berdasarkan hal tersebut, perlu adanya tindakan yang dilakukan untuk mencari jalan keluar dari masalah itu.

Berdasarkan hasil pemantauan dan evaluasi, untuk pertemuan selanjutnya, tindakan yang diberikan sudah mulai mendekati apa yang diharapkan dalam penelitian ini. Masalah-masalah yang dihadapi antara lain:

a. Siswa tidak bermotivasi untuk belajar

b. Tidak disiplin belajar, utamanya mengerjakan LKS yang diberikan sebagai tugas kelompok

c. Tidak percaya diri untuk mengerjakan soal

d. Kurang aktif pada saat pembahasan soal-soal latihan dan contoh soal

\section{B. Observasi Aktifitas Belajar Siswa pada Siklus II}

Data tentang keaktifan belajar siswa setelah pelaksanaan tindakan siklus II dikumpul melalui pengamatan oleh anggota team yang menyangkut rata-rata persentase yang termuat dalam Tabel 2.

Tabel 2. Data Observasi Aktifitas Belajar Siswa Siklus II

\begin{tabular}{clccc}
\hline No & $\begin{array}{c}\text { Aktivitas } \\
\text { Siswa Selama } \\
\text { Pembelajaran }\end{array}$ & \multicolumn{2}{c}{$\begin{array}{c}\text { Pertemuan } \\
\text { ke- }\end{array}$} & $\begin{array}{l}\text { Rata- } \\
\text { rata } \\
(\%)\end{array}$ \\
\hline 1 & $\begin{array}{l}\text { Siswa yang } \\
\text { hadir }\end{array}$ & 30 & 30 & 100 \\
\hline \multirow{2}{*}{2} & $\begin{array}{l}\text { Siswa yang } \\
\text { memperhatikan } \\
\text { dan mencatat }\end{array}$ & 28 & 30 & 96,67 \\
\hline
\end{tabular}


Penerapan Model Pembelajaran Kooperatif Tipe Numbered Heads Together (NHT) terhadap Aktivitas Belajar Siswa pada Materi Ikatan Kimia Kelas X I SMA Negeri 3 Watampone

\begin{tabular}{|c|c|c|c|c|}
\hline 3 & $\begin{array}{l}\text { Siswa yang } \\
\text { tidak } \\
\text { memperhatikan }\end{array}$ & 2 & 0 & 3,33 \\
\hline 4 & $\begin{array}{lr}\text { Siswa yang } \\
\text { aktif dalam } \\
\text { diskusi } \\
\text { kelompok }\end{array}$ & 28 & 30 & 96,67 \\
\hline 5 & $\begin{array}{lr}\text { Siswa } & \text { yang } \\
\text { bertanya } & \\
\text { tentang } & \text { materi } \\
\text { bahan } & \text { ajar } \\
\text { yang } & \text { kurang } \\
\text { jelas } & \end{array}$ & 0 & 0 & 0 \\
\hline 6 & $\begin{array}{l}\text { Siswa yang } \\
\text { aktif dalam } \\
\text { pemecahan } \\
\text { masalah }\end{array}$ & 20 & 25 & 45 \\
\hline 7 & $\begin{array}{l}\text { Siswa yang } \\
\text { menjelaskan } \\
\text { hasil diskusi } \\
\text { kelompok } \\
\text { dipapan tulis }\end{array}$ & 15 & 17 & 53,33 \\
\hline
\end{tabular}

Tabel 2 menunjukkan bahwa siswa yang hadir selama siklus kedua mencapai $100 \%$, yang memperhatikan dan mencatat pelajar mencapai 96,67\%, siswa yang tidak memperhatikan $3,33 \%$, siswa yang aktif dalam diskusi kelompok sebesar $100 \%$, siswa yang bertanya tentang materi bahan ajar yang kurang jelas mencapai $0 \%$, siswa yang aktif dalam pemecahan masalah sebesar $45 \%$, dan siswa yang menjelaskan hasil diskusi kelompok di papan tulis mencapai 53,33\%. Kesimpulan dari analisis tersebut bahwa keaktifan belajar kimia siswa sudah mencapai yang diharapkan dengan indikasi ratarata indikator keaktifan sudah menunjukkan adanya peningkatan yang signifikan terutama kedisiplinan dalam diskusi kelompok, aktif dalam pemecahan masalah.

Setelah refleksi pelaksanaan siklus I, diperoleh suatu gambaran tindakan yang akan dilaksanakan pada siklus II ini, sebagai perbaikan dari tindakan yang telah dilakukan pada siklus I. Hal ini dapat terlihat bahwa tindakan yang dilaksanakan secara umum hasilnya semakin sesuai dengan yang diharapkan. Adapun tindakantindakan yang dilakukan adalah:

a. Menugaskan setiap siswa untuk membaca literatur yang berhubungan dengan materi kimia yang akan diajarkan.

b. Memotivasi siswa yang ragu-ragu mengerjakan soal sambil dibimbing.

c. Menunjukkan bagian-bagian soal yang sulit bagi siswa kemudian menyuruh secara berkelompok mengerjakan sampai benar.

d. Menambah jumlah item soal, agar siswa terbiasa mengerjakan soal latihan untuk di rumah.

Minggu pertama pelaksanaan tindakan siklus II, sudah ada siswa yang mengerti tentang metode pengajaran NHT sehingga ada siswa yang mengajukan diri untuk menjelaskan hasil diskusi kelompok di papan tulis tanpa bantuan dari temannya walaupun masih sedikit. Pada saat kegiatan belajar mengajar berlangsung, sudah ada sebagian siswa yang berani memberikan respon jika guru memberikan pertanyaan.

$$
\text { Memasuki pertemuan }
$$

selanjutnya sehingga pertemuan terakhir penelitian terlihat bahwa dalam proses belajar mengajar, guru telah menemukan metode yang tepat sesuai denga apa yang diharapkan dimana 
setiap siswa sudah terbiasa dengan kebiasaan yang dilakukan yaitu setelah guru memberikan informasi tentang materi secara garis besar, siswa mulai mengerjakan soal secara berkelompok.

Kegiatan siklus II, dapat dikatakan mengalami peningkatan dibandingkan dengan siklus I. Hal ini dapat terlihat dari keaktifan siswa untuk bertanya tentang materi yang dibahas, keseriusan siswa untuk mengikuti proses belajar mengajar, kehadiran siswa dalam keaktifan siswa yang tekah berani mengajukan diri untuk memaparkan hasil diskusi kelompok di papan tulis.

\section{KESIMPULAN DAN SARAN}

\section{A. Kesimpulan}

Berdasarkan hasil tindakan, analisis dan pembahasan yang dilakukan maka disimpulkan bahwa penerapan metode pengajaran NHT dapat meningkatkan kualitas proses pembelajaran kimia pada materi Ikatan Kimia siswa kelas X 1 SMA Negeri 3 Watampone dengan indikasi meningkatnya motivasi dan keaktifan belajar siswa dengan menekankan:

1. Menugaskan setiap siswa untuk membaca literatur yang berhubungan dengan materi yang akan diajarkan.

2. Memberi semangat kepada siswa yang ragu-ragu mengerjakan LKS dengan cara membimbing dan menyuruh secara berkelompok mengerjakan LKS, agar membuat siswa terbiasa dan berani mengerjakan soal baik di tempat duduk maupun di papan tulis.
3. Menunjukkan bagian-bagian soal yang sulit bagi siswa kemudian menjelaskan kembali dengan menyuruhnya berkelompok, perorangan mengerjakan soal tersebut sampai siswa mengerti dan dapat menyelesaikannya.

4. Menambah jumlah item soal agar siswa terbiasa mengerjakan soal latihan baik di sekolah maupun di rumah.

\section{B. Saran}

Upaya peningkatan keaktifan siswa kelas X 1 pada SMA Negeri 3 Watampone Kabupaten Bone dapat dilakukan dengan peningkatan kemampuan mengajar melalui penggunaan strategi pengajar yang dapat melibatkan siswa aktif dalam pembelajaran, maka disarankan kepada guru kimia agar menerapkan metode pengajaran NHT sejak dini untuk meningkatakan hasil belajar siswa dalam menyelesaikan soal-soal kimia dan memacu siswa agar lebih aktif dan kreatif dalam proses belajar mengajar.

\section{DAFTAR PUSTAKA}

Arends, Richard. 2008. Learning to Teach: Belajar untuk Mengajar. Buku Dua. (Penerjemah: Helly Prayitno Soetjipto dan Sri Mulyantini Soetjipto). Pustaka Pelajar. Yogyakarta.

Hobri. 2009. Model-model Pembelajaran

Inovatif. Jember: FKIP, Universitas Jember. 